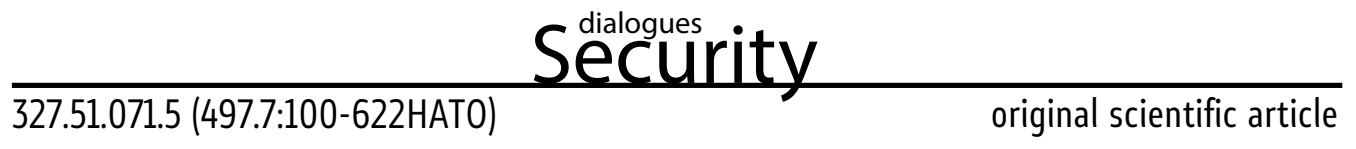

\title{
Macedonia and NATO: Uneasy Path to Membership
}

\author{
Lidija Georgieva, \\ Institute for Security, Defence and Peace, Faculty of Philosophy, Skopje \\ georgieva@fzf.ukim.edu.mk
}

\begin{abstract}
At the beginning of 1990's the public opinion in Macedonia was overly in favour of the European integrations seen both as a priority and an instrument for achieving national political goals. Ever since the process of Euro-Atlantic integration has been perceived both as platform for dialogue and tool for achieving national unity among the domestic political actors usually divided over numerous ideological and ethnic priorities. It was expected that European and Euro-Atlantic integrations, perceived as a common political goal, would facilitate the internal dialogue and raise the level of trust into national political institutions. This paper deals with the longest part of the SSR process a part of Macedonian transitional and integrative agenda. It particularly focuses on periods that have begun since 2005 (when Macedonia has gained candidate status for EU membership) and 2008 (when NATO issued invitation). The research focus is post-Bucharest dilemmas regarding its security policy and defence reforms in Macedonia.

\section{Introduction}

In 1990-ies Macedonia entered process of democratic transition and institutionbuilding. The process was influenced by the variety of internal and regional factors, especially in the period of violent conflicts in the region and their aftermath. This turbulent process and the regional environment created perception that Macedonia was a part of the Balkan in-security community and that it shared its common dilemmas and perspectives (Schnabel 2001). The primary goal of the Macedonian foreign and security policy from the early 90 's has been avoidance of the consequences and contagious effects of the regional violent conflicts, and sustaining the internal stability. NATO membership (Euro-Atlantic integration) was considered an opportunity and essential strategic instrument that would preserve the political will alive and would also facilitate painful reforms. More clear political perspective of NATO membership appeared shortly after independence, once the
\end{abstract}


Macedonian Parliament issued a Declaration for joining the Alliance in 1993. It confirmed the political determination to join the Alliance through a steady process of cooperation up to the full membership. From this moment the relations between NATO and the Republic of Macedonia have undergone different phases and intensity of cooperation.

The initial phase lasted from 1994 when Macedonia joined PfP Program up to 1999 when the first MAP was launched. The timeframe of 2000-2004 encompasses implementation of NATO and EU political and military instruments for peace-building following the 2001 conflict (Georgieva 2005). The most intensive and crucial phase started in 2004 with the presentation and implementation of the Strategic Defence Review i.e. the core political document on defence reforms with specific tasks and goals that had to be completed by the end of 2007, eventually leading to an invitation for membership.

The 2008 Bucharest Summit of NATO was expected to confirm the overall progress by issuing official invitation for membership. However, it turned into a major disappointment: the name issue dispute prevailed over the formal NATO criteria in determining the final decision. The Macedonian authorities as well as the public, with the exception of few independent experts, expressed huge discontent because the decision was made based on an additional precondition (i.e. settlement of the name issue) rather than on the ground of the merits. The governing coalition announced early elections in order to accommodate political pressure. The country went through the most controversial elections with numerous irregularities and even election violence. Such electoral outcome influenced the report of the European Commission on the progress of the country. In general, the Bucharest decision to separate Macedonia from the other two candidate countries, also members of the Adriatic Charter, had a direct impact on the political processes and at first glance increased divisions over future commitment and position towards the negotiation process over the name issue under the UN auspices. Predictions that the failure in Bucharest would hinder future progress slow down the reforms and decrease the public support turned out only partially correct. Right after the elections the government announced its commitment for the security sector reforms and strategic goals. Truly, the public had never had any critical and/or objective stance over cost-benefit aspects of Macedonian membership to NATO; nevertheless, now it divided internally over another question: whether the name/identity should be traded for membership in NATO and/or EU. 


\section{Securiaty}

\section{Security Policy and the Need for Reforms}

Since in 1991, the Republic of Macedonia has been perceived as a country that fairly successfully managed to evade contagious effects of ethno-political and nationalistic climate that dashed through the region. Even more as a newly emerged would-be democracy, Macedonia acknowledged its Euro-Atlantic integration as a way out of transitional traps and challenges. At the same time, integrations and active security policy were considered a core managing and accommodating tool of uneasy interethnic substance. Overall, the reforms and integrations were weighed up to be magic political words that have been offered as a substitute for shortcomings within the political management process. Furthermore, side effects of the transitional reforms were very often justified as necessary and inevitable. What have really happened during this decade was estimated as a slow and difficult reform process overburdened with internal and external challenges.

Macedonia has officially started its cooperation with NATO in 1994 by joining PfP. The cooperation with EU started even later by signing the SAA in 2001. Still, after years of cooperation, the country was not even close to any prospect for membership. On the contrary, the mix of factors compounded of accumulated vulnerability and regional conflict spillover effects have contributed to the creation of internal conflict potential. Before the crises in 2001 was triggered, it had become evident that much of the structural factors such as economic underdevelopment, social security challenges, high unemployment, weak institutions, and high centralization had created conflict potential when mixed with the effects of the Kosovo conflict. As a result, the securitization of the ethnicity, especially educational and human rights dimensions, overshadowed policy dialogue among ethnic elites.

It was evident that the political and economic weakness and restricted institutional efficiency were limiting factors for effective reforms. Instead, there was a perception that $a d$ hoc decisions dominated the processes. Finally, the internationally negotiated Ohrid Framework Agreement (OFA) that ended the seven months' crisis shaped the scope of peace-building process and also influenced the process of SSRs. According to the agreement provisions, the reconstruction of the multiethnic democracy needs to be accompanied by serious reforms of the security sector while significant international support has been provided as a back-up for the implementation phase.

Within such context, the security sector faced serious difficulties. Public expectations for safety and security vis-à-vis the complexity of the regional threats and 
challenges were growing. At the same time, it was expected that the security and defense policy would serve as a key instrument to facilitate integration into NATO and EU. The process of the security sector formation in the early 90 -ies was actually guided by the wish to establish self-sustainable defense model based on the balanced military and police sector. In addition, an effective support from collective security mechanisms was expected to be the third pillar of the defense system. Due to the regional circumstances created by the Bosnian and Kosovo crises, and especially by 1999 NATO intervention, the academic community concluded that national and regional security depend on a number of frozen conflicts.

Since then, logical dilemmas appeared with regard to the security relations among the countries in the region and notably NATO and EU security policy towards the Western Balkans (WB). The expectations obviously differed. The desire for integration of the WB has been growing together with the fear from uncertainty. The expectations were that the prospects for integration would become realistic through the process of gradual and effective fulfillment of membership criteria. Also, it was expected that the process of democratization and norms transfer will decrease the prospects for violent behavior or military resolution of frozen conflicts could be avoided.

From the theoretical perspective, the expectations could be pulled together in the possibility of initiating security behavior among states in the region distinctive for the security community, aiming to create stable security relations and therefore conducive to permanent peace. Väyrynen (2000) summarized theoretical recommendations for achieving a model of security community, thus referring to security as a low probability of using serious coercive force (both military and economic) between or within nations. The security community is described as a collective arrangement in which its members have a reason to believe that the use of military of economic coercion in their mutual relations is unrealistic. Consequently, the dilemma about security relations in the region is whether and under what conditions stable security relations among countries are possible. The goal of achieving full membership into NATO and EU was estimated (at least from experts perspective) as an opportunity and as powerful policy instrument for initiating constructive security relations.

Along these lines, Macedonia continued with the implementation of a twofold model of security policy. That is a true investment in political and economic stability and development of multiethnic democracy through NATO and EU membership, and through institutionalization of OFA mechanisms. As a candidate country for EU membership, the country keeps on strengthening its capacity for democratic and institutional management 
of political and interethnic differences. It is evident that integrations and successful improvement of interethnic relations are mutually reinforcing factors. Politically guided from the imperative for NATO and EU membership, SSR has become cornerstone of a successful and democratic transition. This process in Macedonia seemed more or less specific because of two reasons at least: SSRs had to comply with the core guiding principles of the concept and to accommodate the Macedonian security and defense needs. The SSR reached crucial priority especially after 2001. It was described as a crowded security sector. Up to 2001, this formal force bearing security sector actors were the most obvious and exposed parts of the sector. However, after 2001, the need for reforms and better shaping of the security sector, following the principles of civilian and democratic control over military, transparency and accountability, seemed even more obvious.

\section{Normative Issues of the Defense and Security System and Policy}

The 1991 Constitution of the Republic of Macedonia introduced parliamentary democracy. In accordance to the separation of power principle, the Constitution determines the position of the Parliament to be a core institution in the legislative branch and even strengthened because only the Parliament holds the power for self-dissolving. With respect to the executive branch, the Constitution divides the executive power between the Government and the President of the Republic. According to the experts the relations between legislative and executive branch, or even within each of them, are dependent on the current political situation rather than on the constitutional model. In practice relations between the executive and legislative branch are vague and competing in the process of policy and decision-making. Such situations are possible due to the vague constitutional relations between the Government and the President, but also when the relations between the President and the Parliament are in question.

The President holds significant competences and its position is not only titular unless strictly determined by the Constitution (Articles 79-87). His/her position in the defense sphere is also significant as he/she is supreme commander of the armed forces both in peace and war time. The competences during war or emergency are even more important because he/she is in a position to appoint or discharge the Government and the officials. With respect to the question of how this is to be transferred to a practical procedure, the Constitution is delegating to the Defense Law the obligation to determine the position of the President, Ministry of Defense and the General Staff. The President also 
appoints and dismisses generals and the Chiefs of Staff of the ARM (Army of the Republic of Macedonia).

The Constitution determines the role of the Government. Yet there are no specific provisions on democratic control of the armed forces. Regular functions of the Government apply to the defense sector too, and the Defense Law should specify the relations among the executive, the President and the Government. This was the contesting question because, according to the Defense Law, the President holds a more powerful position. In practice, the cooperation and coordination between the two was necessary, especially in regard to the defense plan or the defense strategy. Another sensitive issue was the position of the General Staff. The Chief of Staff appointed by the President is accountable both to him/her and to the Government.

The Ministers of Defense and the Minister of Interior have to be civilians for at least three years before taking the position. The Constitution secures civilian and democratic control over both ministries and makes them accountable in front of the Government. Ministries are responsible for implementation of the national security policy and are accountable to the Government while the Government is collectively and individually accountable to the Parliament.

The issue of legal ambiguity reflects on the security and the defense sphere. This situation should be overcome by defining more specific and clearer relations among the security sector actors in laws on specific spheres. Once the Constitution defines the core Parliamentary actors it hands over the security and defense issues to be resolved by the Defense Law and the Law on Police. The 2001 Defense Law was expected to provide more clarity on the institutional relations among security sector actors and also to strengthen civilian supremacy over military. ${ }^{1}$

The SSRs were substantially reassessed after Macedonia started accomplishing its core security policy priority - inclusion into the NATO. The Parliament reconfirmed commitment to NATO membership again in 2004 and 2007. At the same time, Macedonia continued to be captured within a regional conflict complexity. In the period to come, the

1 The Defense Law of May 2001 intentionally defined more specifically the role of the Defense Ministry, the mission of the Armed Forces and the role of the General Staff. While it appeared that civil military relations and civilian control and supremacy over military has been accepted as primary principle other issues questioning the role of the executive branch, especially the Parliament in practicing democratic control over security sector, its active role in creating national security policy, or question of accountability and transparency were kept silent. 
process of reforms was frequently imposed to various crisis situations (regional and internal). Essentially, it was recognized predominantly as a matter of the military and defence sector. ${ }^{2}$ The reforms of the military preceded the reforms of the police and other constituents of the sector. The newly established military (ARM was officially established in 1995) initiated the process of composition of the security sector. The police and other reforms came into the process later on. Under specific regional and internal circumstances (overburdened by ethno-political rivalries) this process was observed closer to the concept of security sector formation than security sector reform. Despite all odds, public expectations regarding the SSRs as a precondition for NATO and EU membership remained high.

Signing the Stabilization and Association agreement (SAA) in 2001 gave new impetus for more comprehensive reforms. In fact, the complexity of the reform process was additionally shaped and specified by the provisions of the Framework Agreement (OFA), an act that formally put an end to the seven months' confrontations and crisis in Macedonia. It introduced specific post-conflict peace building policy aimed at rebuilding security and interethnic confidence and stability, destroyed during the conflict. Both SAA and OFA became a guiding instruments and framework for the reforms primarily in the sphere of the rule of law, independence of the judiciary, anti-corruption measures, police reform, and the border security management. ${ }^{3}$ They became essential framework that supported and strengthened the process of institution and capacity building, democratic reforms, strengthening the rule of law and economic recovery. ${ }^{4}$ The application for EU membership

2 The way out of the position of complete recipient of international institutions security mechanisms during the violent dissolution of former Yugoslavia Macedonia tracked trough PfP and participating in other NATO programs that were developed towards the countries of Central and Southeast Europe. Starting as a beneficiary of PfP function of inclusive system of confidence-building, mutual understanding, consultation, and communication and information exchange; in order to provide transparency in security and defence affairs, Macedonia continuously maintained its active security and defence policy trough instruments of PARP, IPP, MAP.

3 See regional Strategy paper 2002-2006, European Commission, External Relations Directorate General, Directorate Western Balkans

${ }^{4}$ Under the CARDS programme a significant number of projects in the field of Home and Justice Affairs were developed in Justice and Home Affairs, Economic and Social Development, Democratic Stabilization, Environment and Natural Resources and Administrative Capacity Building. The sector of JHA was aiming at support reforms in the legal system and judiciary, police reforms, integrated 
overcame in a way the psychological obstacles perceived by the broader public, that reforms are an everlasting and endless process and the progress is hardly measurable.

The historical background of the Macedonian security affairs and implicit political and overall public consensus for EU and NATO membership were the two general factors influencing the process of reforms. The advancement of the reforms in the security and defense sector was perceived as a positive move towards functional and more effective democracy. This is a core motive that influenced and contributed to a high public support for defense and other reforms in circumstances when most of the citizens were concerned about a high unemployment rate and a social insecurity. Since the reforms in the defense sector started as early as the Macedonian participation in NATO programs, and reached some positive effects up to 2001, it became more obvious after the NATO summit in Prague, that there are commitments to be completed if perspective for membership is to remain open. In a way, the Prague Summit of NATO put new emphasis on internal reform process but also on regional aspects of cooperation.

Subsequently, the new framework for continuing defense and wider reforms and for introducing the IBM strategy appeared as the National Security and Defense Concept (NSDC) was adopted. It was the first broader concept related to the security and defense policy adopted by the Government and the Parliament in February 2003..$^{5}$ The NSDC was the basic document that regulated and guided national security policy in general and the security policy in particular. It was more specific regarding internal security policy as directed to protection and improvement of the national interests, resolution of risks and threats directed to democratic order, and the human rights and freedoms. Identifying terrorism, organized crime, illegal migration and illegal trade of drugs, weapons, trafficking in people and strategic material as an essentially complex task, the objective of the security policy is to organize efficient border police and to develop joint operational procedures with

border management, capacity in dealing with organized crime and human trafficking, development of asylum and migration policies, development of legislation and proper law enforcement.

${ }^{5}$ Although during the procedure of drafting the document and later in public debates divergent opinions about the National Security and Defence concept were presented, especially on the issue of the conceptual understanding of the key categories, about basic interests and security risks and threats, it was evident that the political and expert communities stick on different opinions on certain topics of the document. 
the armed forces, especially to fight terrorism and maintain border security. ${ }^{6}$ In addition, the Parliament adopted Law on Crisis Management that clarified certain aspects of cooperation and coordination among the executive institutions, particularly between the police and the army in the case of emergency and crisis situations.

The adoption of the 2004 Strategic Defense Review was another impulse for the reforms. The document represented policy guidance for defense and other sectors that should act in harmonized manner to meet the NATO criteria. In addition to the PfP program and MAP, it created basis for transformation of the defense system from a based on conscription and territorial defense to a one that would be fully professionalized by 2008 . According to the provisions of the SDR the Macedonian Army should respect the principle of de-politicization, to approach restructuring and downsizing with targeted strength of 8460 individuals planed for 2007, ensure appropriate representation of all ethnic communities (25\% of all positions within the ARM, goal projected for 2013), modernization of equipment, and transfer duties for border protection to Border police. Such a complex and demanding reform agenda was divided and pursued through MAP and ANP's on preparation for membership, instruments to guarantee that the country meets the requirements for full NATO membership.

The regular PARP process enabled enhancement of interoperability between Macedonia and NATO in the areas of peacekeeping and humanitarian mission. The 2007 PARP process was the last assessment of the Macedonian efforts before Bucharest Summit in completing defense reforms and fulfillment of criteria for membership. It identified several positive issues such as: maintaining high priority for NATO and EU membership; achievements in regional cooperation through the SEDM process and Macedonian chairmanship from mid 2007 to mid 2009; cooperation and partnership within the framework of Adriatic Charter; development of a new National Security Strategy and updating Defense Strategy; coordination through the Committee for NATO integration and substantial level of political leadership; commitment and contribution to NATO and EU lead operations; established full operational capacity as Host Nation Support Coordination Centre for KFOR support tasks since 2007; introduction of Ministerial Guidance for Development of Long-Term Plan for Defense (2008-2017) and improvement of equitable representation of ethnic communities. However, some open issues were identified in regard

\footnotetext{
${ }^{6}$ See National Security and Defence Concept of the Republic of Macedonia; available at: www.http//:vlada.gov.mk.
} 
to modernization programs and equipment as well as the issue of air surveillance and connectivity with NATINADS. There is also a question of adjusting the legislative i.e. Defense Law for having Macedonian forces participate into collective defense and/or entry of the Allied forces for the same purpose.

\section{Post Bucharest Dilemmas: Prospects and Conclusions}

Bucharest Summit final Communiqué pronounced that Macedonia had fulfilled the criteria for membership. Yet it did not get an official invitation. It related to the so-called "name issue" and good neighborhood relations thus specifically providing one of its members with additional tool for practicing power policy in the UN process of negotiation that lasts over fifteen years. The decision initiated public dissatisfaction for it was perceived as unjust. The pressure and demonstration of political power only reinforced public perceptions that there is imbalance of power and this is an asymmetric conflict. In such circumstances, the name issue becomes a securitized one, as both sides perceived it as a matter of survival and focal point for maintaining its contemporary identity. From this viewpoint, the solution is no longer situated only in a compromised - mutually acceptable decision. It should also include guaranties for uncontested identity, mutual respect and sound political and overall cooperation.

The Bucharest Summit obviously determined the future Macedonia-NATO relations within the framework of the previous institutional context: MAP and ANP for membership. Initially it seemed that disappointment would prevail over pragmatism but it was not the case. In September 2008, Macedonia submitted the Annual NAP, and in January 2009 - the fourteenth IPP 2009-2010. At the beginning of 2008, Macedonia started a new process of defense reforms and transformation of the ARM. The goal was to establish a small and professional army with higher operational capabilities and deployable capacities for international missions, mobility and effectiveness. In addition, forty-four partnership goals were accepted (21 new ones) in order to improve capabilities and to complete the equipment and modernization plan for 2008 . The financial support was provided as $20 \%$ of the defense budget is allocated for modernization and equipment thus meaning that on long-term basis i.e. for a 10 years' period, 392 million euro will be provided.

National Security strategy and Defense Strategy were prepared in 2008. It is expected that the new strategic framework would determine future development of security and defense system based on a long-term Plan for developing defense. According to ANP 
2008-2009, NATO membership remained a strategic priority for the country based on: implementation of the responsibilities according to ANP 2008-2009; Contribution to regional and international peace and security through participation in current and future missions leaded by NATO and other peace support missions; Continuous participation in international activities on fight against terrorism, non-proliferation of weapons for mass destruction, as well as dealing with other contemporary threats for peace and security; Continuous cooperation within PfP and EAPC; Strengthening bilateral relations with NATO member states and partners; Capacity building for the Mission of the Republic of Macedonia in NATO Training and education and Completing the project for restructuring and strengthening bridges.

As part of its regional security policy, Macedonia continue closer subregional cooperation among A-3 countries initiated during the Prague Summit. It was believed that joint activities of three countries would speed the reform processes. In May 2003 the three countries and the US signed the Charter based on principles of partnership: full EuroAtlantic integration as a common goal; democratic reforms, human rights, economic reforms and cooperation, and regional stability. Since the Bucharest Summit, the cooperation among the three countries has been intensified, resulting with an introduction of joint activities that contributed to confidence building. Regular annual meetings on both political and level of military representatives, have created a network for institutionalized policy and security cooperation related to: consultations on security and defense policy, military education, military-technical cooperation, consultations on control of armament; cooperation in peace support and peacekeeping missions; border control and exchange of information; fighting terrorism; media support for defense reforms and annual trilateral meetings on level of MoD. Institutionalization of defense cooperation among A3 countries was in addition strengthened through an implementation of annual partnership plans (Partnership plan for the implementation of USA-Adriatic Charter) based on the specific initiatives of the partner countries following their needs and interests. Continuous trilateral consultations and cooperation also confirmed the need for intensified and broader regional cooperation that will facilitate security relations among the countries. Since it becomes obvious that open or latent challenges are still part of regional security and defence agenda, there is a need for continuous and close cooperation and inclusion of new partners within A3 framework. At the beginning of 2009, a new Partnership plan for implementation of USA-Adriatic Charter was accommodated among partners in Tirana. 
The contribution of Macedonia to international peacekeeping and humanitarian mission is also estimated as a positive experience. Since 2003, 3.200 personnel were deployed to NATO, EU and other operations. Macedonia contributes 11 troops to the EUFOR ALTHEA mission. Macedonia has declared forces for 2014 for the European union Battle Groups - EuBG 2014-2, contributing 130-150 troops as part of the force protection company, as well as staff officers and a national support element. Guided by the general goal of continual development of the military capacities and capabilities required for accomplishment of strategic defense missions, in January 2014 the Government adopted the 2014-2023 Long-term development Plan of the Army. The 2014 budget revision was adopted in September, 2014. Upon the revision, the budget was decreased by MKD 324 million. The revised budget amounts to MKD 5,742,745.000 (about Euro 94 million) i.e. 1.15\% of the GDP. The 2015 draft budget of the MoD is set to MKD 5,852,066.000 (about Euro 96 million) or $1.12 \%$ of the GDP. Taking into account previous experience and lessons learned, the projection is to have 250 personnel by 2018 and to increase this capability to $8 \%$ of overall land forces strength. To some extent, this could be considered as an ambitious commitment having in mind its political and financial aspects.

This is in close connection with another important question: public support for the SSRs and for NATO membership. Until the Bucharest Summit, the high percentage of public support (between 80 - 90\%) was explained in two ways: the public is not properly informed about positive or negative consequences of the membership or, that uncertainty and insecurity, which Macedonian citizens did perceive, contributed to such high support. After Bucharest, public support for NATO slightly decreased but remained high. According to a 2008 survey, $50 \%$ of respondents believe the membership is most important, while another $38 \%$ believe it is important but not a priority. On the question how one will vote on a referendum for NATO membership, 85\% will vote in favor of membership because they expect more stability and economic development. The respondents split the answers and $50 \%$ believe that NATO did not change its relations with Macedonia after Bucharest Summit but $69.9 \%$ answered that they are against change of the name of the country on the expense of NATO membership. 


\section{Conclusion}

The processes of security cooperation and integration into NATO and EU have been the core issues in providing country and its security and defense institutions with support and experiences in accomplishing SSR's. The 2005 European Council decision to grant Macedonia candidate status has invoked a new pace of reforms thus guiding processes of transformation, democratization and decentralization as a basis for promoting an effective multiethnic democracy.

The SSR is considered a principal reform process that succeeded in creating space and favorable conditions for political and other institutional reforms. The overall expectations are that after pursuing of the 9th circle of MAP and ANP 2007-8, the country will complete and reform goals will result in issuing invitation for NATO membership. Instead of joining other two countries from A-3 into finalization of membership procedure, after Bucharest Summit the country has had to overcome challenges regarding its security policy and NATO integration vs. name issue but also to relax public disappointment.

The Bucharest Summit decision, alongside the conclusion that the country fulfilled membership criteria, obviously has directed the future of Macedonia-NATO relations within the framework of previous institutional context: MAP and ANP for membership. The forthcoming period could be probably an extraordinary test about how the partnership and cooperation between Macedonia and NATO will proceed given the fact that Macedonia is still facing the challenges on the way to preserve and to sustain as unique and successful multiethnic democracy.

Having into consideration that SSRs are long term and cyclical process one of the core priorities for Macedonia is to keep both political and financial capacity and public support for reforms. On the first place it means to maintain clear political vision and to pursue effective security policy on country's integration into NATO and EU. On the second place this means continuous and effective implementation of SSRs.

Finally, the key issue for Macedonia is to reach and maintain its capacity of credible and reliable security partner of NATO, its members or with other partner countries. According to numerous analyses Macedonia has gained significant capacity it should be expected that the country would go one with its policy of strengthening security cooperation thus contributing to peace and security of the country and of the region. 


\section{Securiaty}

\section{Bibliography}

1. Adriatic Charter - 2003

http://www.adriaticcharter.gov.mk/thecharter.htm.

2. Annual National Program (NATO MAP), www.morm.gov.mk/english/annualnational.htm.

3. "Aspects of National Security of the Republic of Macedonia", Skopje: Institute for Sociological Legal and Political Research, 2001

4. Bohnet H.: "NATO after Bucharest", Political Thought, no. 22, June 2008

5. Georgieva L., "Macedonia vs. Integrations: From Pperational Prevention towards Conflict Transformation". In "Macedonia and the Region towards EU and NATO" Proceedings from the Regional conference, FES, 2005

6. Defense Law. http://www.morm.gov.mk/english/defencelaw.htm

7. Dimitrov, N.: "Macedonia and NATO: Evolving Partnership The Macedonian Foreign Policy", Crossroads, 01/2006, available at: www.ceeol.com.

8. Ebnöther Anja H., Philipp H. Fluri, Predrag Jurekovic (eds.) Security Sector Governance in the Western Balkans: Self-Assessment Studies on Defence, Intelligence, Police and Border Management Reform, Vienna and Geneva, 2007

9. Milososki A., "Macedonian Perspectives and Challenges", Political Thought, no. 22, June 2008

10. National Security and Defence Concept of the Republic of Macedonia -2003 . http://www.morm.gov.mk/english/nationalconcept.htm.

11. Pack D., "Macedonian and the Western Balkan European Perspective", Political Thought, no. 22, june 2008

12. Pietz T.: Defence Reform and Conversion in Albania, Macedonia and Croatia, Bonn International Centre for Conversion, 2006, Brief 34, BICC, Bonn

13. Schnabel A.: Southeast European Security: Threats, Responses and Challenges, NOVA, 2001

14. Strategy for the transformation of the Defense and the Army of the Republic of Macedonia - 2004. http://www.morm.gov.mk/assets/transformation.doc

15. Strategic Defence Review - 2003 http://www.morm.gov.mk/english/strategicdefencereview.htm. 


\section{Securiaty}

16. Väyrynen, Raimo (2000), "Stable Peace Through Security Communities? Steps Towards Theory-Building", Occasional Paper, The Joan B. Kroc Institute For International Peace Studies

17. White Paper on Defense - 1998

http://www.morm.gov.mk/english/Assets/whitebook.pdf. 